\title{
Evelyn Fox Keller, The Mirage of a Space Between Nature and Nurture, Duke University Press, Durham-London 2010, pp. 107
}

Over the last several dozen years a philosophical reflection on science and the relationship between nature and culture (or, in another version, between nature and nurture) was marked by the so-called "science wars". A stereotypical view of this debate is that it involves two extremely distinct groups of intellectuals: constructivist-relativists, for whom everything depends on cultural and social factors, and naïve realists who believe that world is exactly the way it is presented by (in their opinion) objective sciences (which are in turn mostly independent of any cultural forces).

The books like The Mirage of a Space Between Nature and Nurture by Evelyn Fox Keller show us that, fortunately, the whole discussion can be, and in fact very often just is, more subtle than in the above-mentioned simplistic picture. If one wanted to assign Keller to any of these two groups, perhaps it would be tempting, at least for some people, to consider her as a constructivist. She doesn't believe that nature itself determines properties of the reality as we perceive it. To be more specified, Keller doesn't think that genes themselves determine properties of any human being. Furthermore, she is not even convinced there is reason to talk about genes as separate entities. This is why we can easily assume that her point of view is very different from the one presented by realists like Steven Pinker who believes that there is such a thing as a universal human nature and that it has biological, genetic foundations. Pinker in his famous The Blank Slate claims that vast amount

1 Institute of Philosophy, Faculty of Humanities, Nicolaus Copernicus University in Toruń, Poland, markiewkatomasz@gmail.com. 
of our attitudes and behaviors, including a tendency to commit criminal acts, are determined by our genes and are heritable. He writes: "The unfortunate wretch who is introverted, neurotic, narrow, selfish, and undependable is probably that way in part because of his genes [...] Study after study has shown that a willingness to commit antisocial acts... is partly heritable” (Pinker, 2002, p. 50). That is the kind of statement which is incompatible with Keller's approach.

But, on the other hand, Keller doesn't use any of the classical arguments which are identified by conventional wisdom with a constructivist approach. She doesn't speak much about cultural and social factors. And she definitely doesn't claim that, to paraphrase Stanley Fish's slogan, "nurture is the only game in town". We will not even find in her book a term "constructivism", much less "social constructivism”. In that sense she presents the way of writing about the nature/ culture (nature/nurture) issue which was discussed by Ian Hacking, a well-known philosopher of science. According to him, every time we introduce terms like "social constructivism" or "constructivism", we introduce much confusion to our discussions. It doesn't mean that Hacking is against social constructivism. His point is not about this particular viewpoint, but about the term itself, no matter if it is used by proponents or by opponents of social constructivism (Hacking, 1999).

So how does exactly Keller deal with nature/nurture problem? Her approach is basically to look closely on what happens in the field of biology. And when we do it, says Keller, we will find out that biologists themselves are very careful when it comes to speaking about functions of genes. For example they do not say that a gene $\mathrm{X}$ is responsible for a property $\mathrm{Y}$ of a person $\mathrm{Z}$. Why? One reason I have already mentioned. According to Keller, when we recognize what is the current state of knowledge of genes, we will understand that the concept of a gene, considered as a separate, individual entity, is a very problematic one. As she puts it: "Strictly speaking, the very notion of a gene as an autonomous element, as an entity that exists in its own right, is a fiction. In order for a sequence of nucleotides to become what is conventionally called a gene requires that the sequence be embedded in a cellular complex that not only reads, translates, and interprets that sequence, but also defines it, giving it its very meaning” (Keller, 2010, p. 6). She claims that it is better to speak about DNA, not genes, because "DNA is [...] a concrete molecule - an entity that can be isolated and analyzed, identified by its distinctive physical and chemical properties, and shown to consist of particular sequences of nucleotides” (Keller, 2010, p. 50). But still we should be careful and remember that “by itself, DNA doesn’t do anything”, because there are complex relations between DNA, RNA, and protein molecules in our organisms (Keller, 2010, p. 51). 
And even if we put aside the problem of choosing from human body one, separate entity which is responsible for our development, it is simply impossible to determine to what extent internal, innate, inheritable factors influence any specific characteristic of individual human beings. Keller gives an interesting example to make this point. She proposes to imagine two persons, Billy and Suzy, in two different situations. In both they fill the bucket with water. But while in the first one they use different hoses (so we can determine how much of the water in the bucket was delivered by Billy and how much by Suzy), in the second one Billy turns the tap on and Suzy is responsible for holding a hose (and thus it is impossible to settle how much of the water was delivered by Billy and how much by Suzy). Keller argues that the latter version of this example gives us better understanding of the relation between nature and nurture that the former. It is simply impossible to point out precisely to what extent a personal trait is created by nature and to what extent it is created by nurture (or any environmental forces).

Keller notes also that when we speak on genetic influences we should ask not about any particular trait, but about trait differences. She gives another example (taken from Hans Kummer) to make this point clearer. There is no sense in asking whether the drumming we hear is created by a percussionist or by his instrument - both ingredients are essential. But when we hear two different kinds of drumming, we can reasonably ask whether the difference is due to different abilities of drummers or different drums they use. Similarly, although we shouldn't ask how much of Suzy's height is "created" by genetic factors and how much by the fact that she drinks a lot of milk, we may deliberate in that way on the difference between Suzy's height and Bill's height. It doesn't mean that such a question can be easily answered, but at least it makes more sense than the first one.

Another confusion pointed out by Keller is confounding individuals with populations. Too many times people who write about genetic influences erase distinction between analyses of differences between two persons and analyses of differences between two groups of people. According to Keller it is a rampant problem "among behavioral genetics, evolutionary psychologists, and journalist alike, in popular and semipopular literature as well as in technical journals” (Keller, 2010, p. 55). It is connected to another confusion, namely, between different meaning of the words "heritable" and "heritability". In the technical, professional sense heritability is not about transmission of properties between individuals (first sense), but about relations between the phenotypic variation in a given population and the genetic variation in that population (second sense). Yet very often the word is used in that first sense, which leads to many misunderstandings. Moreover it is frequently assumed that researches on heritability show how a particular gene 
transmits specified properties, even as those researches in fact say nothing about mechanisms of conveying traits. Keller gives an example of IQ surveys to warn against jumping to conclusions too quickly. Even if we know that in a given group of people IQ is passed on from generation to generation, she says, it doesn't mean that it is due to a genetic mechanism (cultural factors may be at work), still less that it is transmitted by genes from a particular parent to a particular child.

Keller wants to leave us, after reading her book, with at least two messages. The first one is that we should be very careful when we use words like "gene" or "heritability". Their meanings are not clear and they can be misleading not only to readers, but also to authors who use them. The second one is that maybe instead of focusing on a question whether a given trait is made by nature or by nurture, we should ask "how malleable individual human development is, and at what developmental age” (Keller, 2010, p. 84). Those are good advices. And they are put in a calm and elegant way. Keller doesn't accuse, she doesn’t panic, and she doesn't want to play a role of someone who changes everything. She just wants to remind us that when we engage in nature/nurture debate, we deal with very complicated issues. And that this debate is not only about science and human beings but about language as well. All our arguments, good or bad, are conveyed and shaped by the linguistic medium. We should never underestimate its force and its influence on how we talk and think about any important matter.

\section{References:}

Hacking, I. (2000), The Social Construction of What?, Harvard: Harvard University Press. Keller, E.F. (2010), The Mirage of a Space Between Nature and Nurture, Durham-London: Duke University Press.

Pinker, S. (2002), The Blank Slate: The Modern Denial of Human Nature, New York: Viking. 